\title{
An Inquiry into the Nature of the Female Mystic and the Divine Feminine in Sufi Experience
}

\author{
Milani Milad ${ }^{1, *(\mathbb{D})}$ and Zahra Taheri ${ }^{2}$ \\ 1 School of Humanities and Communication Arts, Western Sydney University, Locked Bag 1797, \\ Penrith 2751, Australia \\ 2 The Center for Arab and Islamic Studies, The Australian National University, Canberra 0200, Australia; \\ zahra.taheri@anu.edu.au \\ * Correspondence: m.milani@westernsydney.edu.au
}

Citation: Milad, Milani, and Zahra Taheri. 2021. An Inquiry into the Nature of the Female Mystic and the Divine Feminine in Sufi Experience. Religions 12: 610. https://doi.org/ $10.3390 /$ rel12080610

Academic Editor: Denise Starkey

Received: 5 July 2021

Accepted: 3 August 2021

Published: 6 August 2021

Publisher's Note: MDPI stays neutral with regard to jurisdictional claims in published maps and institutional affiliations.

Copyright: (c) 2021 by the authors. Licensee MDPI, Basel, Switzerland. This article is an open access article distributed under the terms and conditions of the Creative Commons Attribution (CC BY) license (https:// creativecommons.org/licenses/by/ $4.0 /)$.

\begin{abstract}
This article is an inquiry into the nature of the female mystic and the divine feminine in Sufi experience. It considers this experience in the general sense with regard to the Sufi tradition, but in its analysis, the article primarily draws on examples from the classical period of Sufi history. Based on an analysis of the thought of key Sufi figures from that period, the assertion is made that the ground of the sacred is female and, as such, the basis of mystical experience is feminine.
\end{abstract}

Keywords: Sufism; female mystic; divine feminine; phenomenology; history; mysticism

\section{Introduction: Overview and Approach}

Recent notable studies have successfully captured the role and significance of women in the history of Sufism. These have also addressed particular issues in relation to gender, religion, society, culture, and politics within the context of Sufi history, with some focusing on the study of Sufi women from various regions of the world, including the Near and Middle East, the Subcontinent, North Africa, Indonesia, and North America (see, Diaz 2015; Pemberton 2010; Taheri 2011; Shaikh 2012; Abbas 2002). There are also studies that provide detailed accounts of the Sufi position regarding the female and feminine in Islam (see, Elias 1988; also, Bashir 2011). Such studies have underlined the significance of the divine feminine, with special reference to Ibn Arabi, in recognition of the feminine attributes of the divine behind the veil of female corporeality. Even so, such analyses performed within the established paradigm of Islamic thought foreground the visibly traditional outlook in Sufism. ${ }^{1}$ Works that concentrate on gender too have provided insight into the complexity of gender as both concept and lived experience within the Islamicate world. ${ }^{2}$ Our task, in this brief study, is to give due attention to two phenomena: the phenomenon of the female mystic and the phenomenon of the divine feminine, both as they are found in the history of Sufism. What we hope to discover is whether mystical experience and, thus, the source of that experience is feminine in nature, so far as can be discerned. Our method is, however, philosophical to the extent that it consists primarily of the task of thinking about the nature and meaning of the phenomena in question. We thus proceed with a view to seeing what might be possible in terms of what the analysis yields about its understanding in spite of established views about the subject of our investigation. There are, thus, three parts to this study: (1) the female mystic (2), the divine feminine, and (3) comparative analysis of two Sufi women from the late medieval period. Parts One and Two deal with the historical and phenomenological aspect of the female mystic and the divine feminine, whilst Part Three will address the phenomenological structure of these with reference to two case studies. This work is in fact connected to an earlier publication (Milani and Krok 2020) wherein holiness was shown as traditionally marked by its antipathy toward the female and feminine in Sufism, despite the propensity of some key figures for overcoming this attitude. In the present work, the hope is to demonstrate reasonable grounds for making 
the assertion that, in fact, the ground of the sacred is female and feminine-in building on the thought of certain Sufis-if we look beyond the screen of androcentrism and patriarchy.

The common understanding from tradition is that mystical experience is about the transcendence of self and, thereby, one's corporeality, in pursuit of the divine, wherein celestial unification is sought. This outlook presents the problem whereby corporeality, in being reduced to mere superficiality, is thus taken as having lesser significance in comparison to the non-corporeal aspect of the self as spirit or soul. However, this does not always and perfectly align with what is observable about the experiential nature of Sufism. We give consideration to the alternative, where mystical experience constitutes the embodiment of the sacred in human experience-without recourse to the redundancy of corporeality in mystical experience-to which numerous examples from Sufi literature testify. This is because it would appear that Sufi tradition has in fact made a consistent effort to homogenise Sufi experience in accordance with traditional Islamic metaphysics, and where anomalies are found, they have been ignored or glossed. The thought of Ibn Arabi presents one such major anomaly in Sufi historicising. Rumi's poetry, another. However, both seem to understand something more arcane than ordinarily perceived in traditional Sufi hermeneutics about the divine, and it is this that has impressed upon us to look closer at the phenomena in question.

Whilst Islamic, the argument has been made that Sufism is phenomenologically correlative to experiences of the sacred prior to Islam (Milani 2014). As such, and as a first point in our inquiry, we need to consider the mystery-cult in relation to our examination of the female mystic and the divine feminine. Before we proceed, however, a more preliminary clarification needs to be made with regards to Ibn Arabi's conceptualisation of the feminine, as this seems to have had a more direct impact on a tradition of interpretation in Sufi thought. Without recourse to the full complexity and nuance in Ibn Arabi's philosophy, we can simply say that Ibn Arabi held that Allah (al-wahid) is between two feminine qualities: "His own secret Essence [al-dhat] ... and the world which comes from Him [al-khalq]" (Austin 1984, p. 7). This tells us that although Ibn Arabi took the contentious view that the essence of God is feminine, he nevertheless simultaneously retained the view —so far as it is evident-that God, as He is, is masculine. His triune conceptualisation of God in Islam is unique, and whilst Ibn Arabi's thought on the matter maintains the significance and centrality of the divine feminine and the pre-eminence of the female mystic, his view allows for the now predominant position that the relationality of both aspects of the masculine and feminine are functionally essential to understanding the mysteries and meanings in Islam. Ibn Arabi's is, therefore, the classical representative of the generally favourable androgynous defense, both metaphysically and ontologically.

\section{The Mystery-Cult and Mysticism among the Monotheisms}

The religion of the ancients was unreservedly more attuned to the sacred feminine (see, for example, Ruether 2005; also, Cusack 2009). One can provide a long list of goddesses that were revered and feared equally as the gods. However, a dramatic shift occurs with the rise to prominence of the monotheistic faiths wherein the divine feminine is brought increasingly under scrutiny until it is marginalised and, in some instances, utterly relegated to the esoteric and the occult within these traditions. The Sufi tradition, like Christian mysticism and Kabbalah, is one such space within the great monotheisms that the presence-or at least the appreciation — of the divine feminine can still be observed. This, in short, is because of the far-reaching influence of the mystery-cult. These are the Greco-Roman mystery religions such as the well-known Eleusinian mysteries, Mithraism, and Orphism, amongst others.

The mystery-cult is the historical antecedent to mysticism as found in the monotheistic traditions of Judaism, Christianity, and Islam. Mysticism in the latter, however, reflects the Platonic appropriation of mystery-cult, that is, their treatment of mystical experience is quintessentially a Platonist one. Yet despite this, the embeddedness of prominent aspects of the mystery-cult nevertheless persists. Of the more prominent is the cult of Dionysos, from 
which we obtain the continuity of the significance of altered states of consciousness through ritual and libation (even if the role of blood/wine is retained only symbolically in Persianate Sufi literature, see Milani 2014 for more on this) (for an early but important critical study of Dionysos see, McGinty 1978). This deep history of mysticism is compounded by the later and highly influential strand of Platonic philosophy: Neoplatonism. It had a considerable bearing on developments in the intellectual history of Islam, including the elaborate doctrines of most Sufi articulators of mysticism. However, along with inheriting the Greek logic for solving metaphysical problems, the Islamicate world also inherited the longstanding philosophical discords of that world. For starters, the Dionysiac cult, whilst being otherworldly, was not world-denying, whereas Plato adapted mystic doctrine with the view to reject this world (Seaford 2006, p. 83). The latter's philosophical-mystical agenda clearly prevails in the theological outlook of all three monotheisms, underpinning the religious mindset of key intellectuals such as Augustine, al-Ghazali, and Maimonides. Yet, so too does the persistence of the Dionysiac mystery of communality and deeply emotive core. Another point of contention is the patriarchal ethos in Athenian philosophy and the mythological and enigmatic role of the feminine in the ancient mystery-cult. Dionysos, for instance, was a major proponent for the collapse of boundaries and the dissolution of opposites. In this sense, for example, the incorporation of the Dionysiac frenzy by Plotinus, the prime Neoplatonist, enforced what he advanced as the totalising prevalence of the One (Seaford 2006, pp. 105-18, 151).

The point that needs to be kept in mind when observing the phenomena of the female mystic and the divine feminine in Sufism is that the tension between the Dionysiac and the (Neo-)Platonic remains pervasive in Sufi thought (see, Jeanmaire 1951; Sedgwick 2016). This has a significant bearing on how the two phenomena come to be viewed, rather differently we might add. It is indeed an extra layer of complexity that already undergirds the older tension/conflict of the monotheistic and Greek paradigms. Therefore, it is in keeping with the deeper and more ancient mode of the mystical that the assertion is made here that mysticism-within which the most hidden aspect of the divine sacred resides - is essentially feminine. What we find with the Platonic experience, broadly, is the masculinisation of what is argued here to have been an originally feminine phenomenon. This brings us to our first quandary: if mystical experience is feminine, does this mean that the essence of the monotheistic God is feminine?

It would seem that mystical experience should not be gendered, since both male and female have access to it equally. Let us consider, then, the same situation in religious experience, generally. Is it masculine or feminine? One would be correct in saying that it is neutral, but what correspondence would such a statement have to the truth of the situation? That is, the truth pertaining to the experience of religion. Were we to say that because traditional Islam is tempered by patriarchal overtones, it would not be an untruthful statement to make about the nature of that experience as masculine in nature, even if it does seem somehow to be incorrect. Therefore, it would also correspond to that same truthfulness to say that mysticism is feminine in nature, for it is the enigmatic, unseen, i.e., the mystique, of that religion. It would then be the Apollonian imperative-in the face of the Dionysian - that would want to rationalise and downplay or even neutralise any such distinction for the sake of putting forward a neater theology of unanimity. However, mystical experience is ubiquitous, and so a greater problem emerges - that is, if we agree about the pre-eminence of the feminine in both mysticism and the sacred-when we consider the experience of the female mystic as a corresponding activity of the presence of the divine, which is in essence itself feminine. Yet can such a relationality be conceivable in Sufi experience? It would appear so. In the first instance, it was proved by Ibn Arabi in his theory of monism that neither is the divine fully absent from the human experience in question nor is the sacred wholly separated from the human in spite of the strict Islamic view to uphold God's absolute non-corporeality. What remains is for us to now demonstrate by way of what can be gleaned from the available evidence that the source of the divine referred to by the mystic is indeed feminine. 
The distinction between 'male' and 'female' in Sufi experience is, therefore, not arbitrary as conventionally thought. Nor can it be two aspects of the one force, such as, for example, yin and yang complementarity, as has been earlier suggested (see, Murata 1992). Sachiko Murata's famous hypothesis (1992) is seemingly helpful in so far as she alludes to the possibility of a more daring Islamic conceptualisation of God as inclusive of feminine and masculine qualities, but in fact, it is misleading with regards to a more fundamental understanding of the divine in Islam, in particular, in the light of the antiquity of that mystical experience. We are not interested here in what seems to be appropriate; rather, our focus is directed toward the inception of the divine in Islam. By inception, we refer to the pursuit of understanding the meaning of the divine in Islam and not merely the historical beginnings of an idea. To start, there are numerous inconsistencies that prevail in textual sources, not least the inconsistencies that are prevalent in traditional discourse on the subject. The Quran, which is the basis of the traditional account, stresses that the male and female do not exist in the eyes of God, that is, that both man and woman are equal before Him (e.g., 16:97). The problem remains, however, that the implicit masculinity of the divine remains the leading interpretation in any discourse regarding mystical experience. This is because first and foremost Allah ("the god") is rendered linguistically masculine due to the Arabic pronoun $\mathrm{Hu}[w a]$ ( "He")- -hence "His" and "Him", providing the common reference throughout the Quran. This is not to say that medieval commentators had not made the case for the 'he-ness' of God as beyond gender (consult Kars 2019, pp. 17-20; on the explication of views within Sufi tradition that push the boundaries of conventionality, see Langhi 2009; Geoffroy 2016). Regardless, it is the patriarchal strand that generally takes hold in the interpretation of religious experience in Islam, including its dominance over mystical literature as well. The claim here is not that the masculinity of 'Allah' in Islam creates patriarchal exegesis. Perhaps male-anthropomorphic theology was what the advocates for a unitive metaphysics, as Kars explains, were hoping to leave behind (on anthropomorphism in Islam, see Holtzman 2019). Rather, if anything, we might say the masculinity of patriarchal exegesis is the cause of 'God' as masculine. Indeed, the masculine perceptibility of God in Islam is so familiar and close to the patriarchal mindset that it would operate in the background of religious thinking about 'Allah', despite any technical variance to it that has been asserted by the scholars. If so, then the androgynous defense - taken up by medieval scholars advocating for 'God' as transcending the male and female binary-seems to be nothing more than a slogan. There is no denying the fact that 'Allah' is generally, but also ultimately, perceived as masculine, even where effort has been put into grammatical arguments to the contrary. The scholars may take care to use technical language to avoid the masculinisation of God, but this has very little impact on the general mood of how God in Islam, let alone Judaism and Christianity, is seen both historically and in the everyday. Given the above, there would, of course, never be the need for an exegete-albeit, a traditional one-to discuss God's masculinity and then relate this to men's superiority over women. It is already implicit.

As the outlier, we suggest that divinity is in essence female, and it is the God of tradition that betrays the patriarchal religiosity reflected in it. The abstract theological argument that Allah is beyond gender is pulled into question in connection with its archaic etymological form, Elah, which is feminine, a fact that Ibn Arabi also recognised (Abrahamov 2015, p. 177). The argument for God as beyond the binary, however, is a conflation of two issues reinforced by the (Neo-)Platonic schema that would influence Muslim rational theology: the prevailing view that Allah cannot be anthropomorphised and that, apart from the use of analogy, personification of Him was forbidden. However, as we have just read, it is so natural to refer to Allah as "Him" ( $h u$ (ه), even if this were a mere linguistic flaw, and the clue is in (the error of) language. Moreover, if the view that 'Allah' should, technically speaking, be gender neutral is successfully defended, it would have to close down any thought of attribution of gender to the deity as reflected in the gender-specific association of human beings with their God. This, whilst noble in intent, is impossible to maintain on the whole. Contrary to the prevailing views (either 
independently or in combination) that God is masculine, that God transcends gender, and that God can be spoken about only in analogical terms with regards to gender, the assertion is made that the experience of the divine is quintessentially feminine. Mystical experience constitutes communion with God, and as such, the correlation cannot be but confirmed: if God's essence is feminine, then the experience of that mysterious source, in the context of mystical experience, must also be feminine. This assertion is in fact not far from the conventional view that God is taken to be a creative force, a lofty and hidden deity, and so through the specialised interpretation of Ibn Arabi about this, it has become possible not only to infer that God possesses a feminine nature but also that the female body can be seen as a metaphor/metonym for God. The seeds of God as feminine are already present in the popular tales of Layla and Majnun, Khosrow and Shirin, and Vis and Ramin, well-known to both Arabic and Persian speaking Sufis. Ergo, not only is it not unfamiliar to historical Sufism that the female mystic is the embodiment of the ideal and the means for comprehending the possibility of union with God but also outlined in such cultural tropes, as the stories portray, the female mystic is the same means to achieving that unity. One can readily derive from the writings of Ibn Arabi, and to some extent, Rumi, the notion of the divine feminine as a feature of God and, in the female, the most perfect image of God reflected (see Taheri 2011, pp. 141-46). However, what is not explicitly discussed, because of the limitations of an ultimately patriarchal tradition, is that the female mystic is representative of what is celestially female in essence and that the divine feminine is the innermost source of God as possible to be attained through mystical experience.

\section{Part I: The Female Mystic}

Annemarie Schimmel (1922-2003), the distinguished Orientalist and scholar of Sufism, was on the right track in her title "The Feminine Element in Sufism", as opposed to, for example, 'women in Sufism', or some such variation of words. The difference between 'feminine' and 'women' denotes a significant shift in focus about the phenomenon in question. "The Feminine Element in Sufism" was published as the second appendix in her seminal work on Sufism, Mystical Dimensions of Islam in 1975. Here, she does underline the role of women in Sufism, historically, but the piece points to the feminine aspect of mystical Islam by documenting key elements of its history that concentrate on the phenomenon of the female, and not just (the gender/sex orientation of) woman. The appendix piece did lay the textual and historical groundwork for what has now become a wide topic of interest. In 1982, Schimmel (Schimmel 1982) published a distilled version of "The Feminine Element in Sufism", focusing on promoting the positive role of women in Sufi history, but nevertheless, in it, she plants the seeds of the idea of the value of the divine feminine in mystical Islam that has since been taken up by scholars from various areas of disciplinary focus. Our reference to Schimmel is partly to pay tribute to her originating efforts toward fleshing out the importance of the divine feminine in Islam via her study of Sufism and partly because of her direct engagement with primary source materials, some of which remain unavailable to the English-speaking world in full. We provide her references as well as the originals wherever possible.

Historical Sufi commentators, such as al-Sulami (937-1021) tell us that there were, to be sure, notable women Sufi whose spiritual achievements were worthy of emulation by both men and women (see, for example, Cornell 1999). Such exemplification of women in historical Sufism is also indicative of a fundamental fact: that Islamic faith and practice were anything but homogeneous. Muslim life, both now and in the past, when observed in finer detail, without fail demonstrates both variety and diversity as a lived religion. This is particularly pertinent to the point about perceptions of women in Islam and Sufism. Such consideration, therefore, always requires careful attention given to context, because the discourse on the role of women continues to be partial to numerous external factors and the way that the latter in turn render religious content. However, there is always the question of how the past is imagined and what it actually was like. We read about the past through books, such as al-Sulami's, but we cannot experience the author's world firsthand. Whilst 
such texts champion respect for women as equals to men, we might ask, do they necessarily represent the reality on the ground? The question of the representation of women in Sufism is admittedly a more difficult subject to attend to than often hoped. The observation made here is that despite the good intentions of some authors and given the general freedoms that Muslim women-especially those living in major civilisational centres (such as Nishapur) as well as those of a higher social standing-enjoyed, the overwhelming presence of male prejudice is generally prevalent. As such, there is no reason to think that historical Sufism would have been innocuous in terms of the general tenor of androcentrism across the Islamicate world. That said, we move well beyond the concern with Sufi women, generally, in our asking about the female mystic.

The question of the 'female mystic' is meant to distance us from (mis)conceptions about women in Sufism. It is to reorient the focus back onto the originary function of mystical experience underpinning Sufism as opposed to seeing Sufi women as an issue pertaining to gender. The topic of 'woman' in Sufism (and Islam, generally) typically depicts that which is paradoxical in nature because what is seen is easily confused with what remains essentially true about the mystical. The question of gender is only superficially relevant as it pertains to social and cultural differences in relation to notions about sex, whereas, if we ask about the female mystic, we are dealing with that which is more fundamental as a condition of being in a mystical state. This paradox, then-which arises from the basic problem of a (mis)take in thinking about the topic - signals where our attention needs to be with regards to our investigation. However, in order to be able to discuss the female mystic, we are required to first say something about the historical context of women in Sufism with regard to its paradoxical nature as noted.

The Sufi penchant for paradox and irony, in particular, as found in the works of such Sufis as Ibn Arabi, Rumi, and Attar, is well-established. It becomes important to climatise to the paradoxical nature of their works when reading and thinking about the role of women in Sufi literature so as to be able to obtain a better sense of the phenomenon of the female mystic portrayed by these Sufi authors. Sufi literature, in general, requires of the reader an appreciation of subtlety and complexity. Sufi poetic works are specially composed with a range of literary tools in mind, including the flexibility of interpretation and the use of symbol to effect. The basic idea in Sufi poetry, for example, such as that of Attar of Nishapur, a figure to whose works we will in a moment turn, is that the author wants to capture emotional and intuitive content as well as to allow for the open-endedness of the potential for meaning conveyed in the text. However, we may encounter another kind of paradox in the literary genre of Sufi works such that even though the poet Sana'i declares that "[a] pious woman is better than a thousand bad men" (Schimmel 1975, p. 426; Sana'i 1950 , p. 271), it is done, no doubt, not out of sincerity but to taunt his male audience. ${ }^{3}$ For the "ideal of the Sufi", said Schimmel, "was always the 'man'”" (Schimmel 1975, p. 426), having full well known the content of classical sources. Still, the dispensation, it will become clear, was that if a woman could in fact reach the level of a man, they would be considered as having achieved "the high ambition of Sufism" (Schimmel 1975, p. 426). ${ }^{4}$ Indeed, Schimmel did say that "[t]he attitude of Sufism toward the fair sex was ambivalent" (1975, p. 426). However, the source of this idea of metaphorical transfiguration is found in Attar's Tadhkirat al-Awliya. He cites Rabi'a al-Adawiyya as the exemplar. She is not only the only woman given her own chapter in the biographical line-up of Attar (other women are mentioned, but they do not have a devoted section to them), but she is the only one in his biographical work to have received the status of manhood. Attar does mention other women in passing and in relation to notable Sufi men, as we will be observing, but they are mentioned only as supplementary figures, at best, and at worst simply as incidental to Sufi history. At any rate, these women, as important as they are, are not given the same kind of attention as Rabi'a. ${ }^{5}$ We must not forget, Rabi'a is the only woman counted as among the greats only because she achieved the status of a man. The paradox becomes apparent: Rabi'a, therefore ironically, is revered among men when she becomes he, the problem being that not only is woman irrelevant but also the female mystic is unseen. 
Cornell's assessment of the representation of Rabi‘a by Ibn al-Jawzi and al-Sulami might be an important distinction, but it is ultimately one without a significant difference (cf., Cornell 1999). When we take a closer look at the issue, and using Rabi'a as representative of the attitude of both authors toward women, the former wants to portray her as the emotional recluse, whilst the latter seeks to show her as the disciplined rational, because the matter bespeaks the motivation of situating womenfolk in their proper role with respect to menfolk. For Ibn al-Jawzi, women are lesser than men, and for al-Sulami, they are equal to them. However, we are left with a bitter taste either way: if it were not an issue that both accounts are in fact merely two variant male readings of Rabi'a, then it might count for something to consider that the first is dismissive of women and the second appropriates them through a masculine reading. The point is that the real option for women seems nothing more than either to be lesser than a man as a woman or be equal to a man in becoming a man. Rabi'a is an ideal Sufi (Smith 1928) because she became a man: "When a woman walks in the way of God like a man, she cannot be called a woman" said Attar (1905, p. 59). ${ }^{6}$ Schimmel's English translation of Reynold A. Nicholson's MS is here noted. More striking is Arthur J. Arberry's translation of the same (below offered in full for effect) (Arberry [1966] 1983, p. 40):

If anyone says, "Why have you included Rabe'a in the rank of men?" my answer is, that the Prophet himself said, "God does not regard your outward forms." The root of the matter is not form, but intention, as the Prophet said, "Mankind will be raised up according to their intentions." Moreover, if it is proper to derive two-thirds of our religion from A'esha, surely it is permissible to take religious instruction from a handmaid of A'esha. When a woman becomes a "man" in the path of God, she is a man and one cannot any more call her a woman (emphasis mine).

Notably, his defence is based on his take on sunna; still, the point to focus on is that the apology is turned on its head when suddenly Rabi'a is turned into a "man" and can no longer be called a "woman". The rationale employed by Attar is, however, the critical point. It has three parts to it: (1) that (according to the highest religious authority) the physicality of the human being - in a Platonic-cum-Augustinian ${ }^{7}$ twist-is secondary, (2) (in fine deflective form) that-and put forward as a 'by the way'-Islam is for the most part learned from a woman (Aisha), and (3) that Rabi'a, in having reached the heights of Sufism, is equal among men, anyway. To seal the deal, Schimmel (1975, p. 426) reminds us that any woman having subsequently achieved the station that she had might be given the honour of being "a second Rabi'a" — that is, a woman that has become a man-but, and here we offer our own observation, this would fail to see the irony as it is both in Attar and in later masters such as Rumi and Ibn Arabi. The irony is that Attar cannot possibly be taken literally as defending such a view and that his statement about women becoming men reflects the popular slogan of the time.

Margaret Smith's now-classic study of "the woman saint" demonstrated that Rabi'a was certainly not the exception (in that she was not the only Sufi woman of her time) but that she was, nevertheless, exceptional. Sufi women contemporary to Rabi'a were no less notable for their saintly qualities, but that they were lesser in importance to the tradition on the whole is noticeable, because, we observe, they had not attained 'manhood' as she had. They are shown to occupy a woman's role in society. Even their practicing of Sufism is made to reflect that they are women. The language used places them in their womanly role as those that are enthusiastic (overwhelmed by emotion and erratic, as opposed to the rational intellectual religious knowledge of the Muslim man) and as those that weep constantly and make others weep, and are fearful— “ $[t]$ hey might even become blind from constant weeping, so that their hearts' eyes might see better", adds Schimmel (1975, p. 426). This latter is surely a compensation for the "fair sex" from the point of view of what was by then already an established androcentric tradition. The study of Smith and Schimmel reveals something easily overlooked: that which is defined (or confined) to the female is also what captures the quality of the mystical. This is to turn on its head the story of the woman saint in Islam in order to show the nature of the Sufi woman more favourably. To 
use the example of Rabi'a, what we see is the masculinisation of the mystical, which some agree to be the sign of equality. What is spiritual might be properly the realm of men - by virtue of, say, conceding that in biblical terms the "Spirit of God" is analogically a masculine entity — and thus masculine, but the mystical—by virtue of what might equally be ceded as typically gendered references to the hidden, soft, fertile, and womblike-is properly the domain of the female and hence feminine. Hence, we maintain that the difference of the masculine and feminine, in this sense, is important as opposed to what is commonly perceived as the masculine and feminine as two aspects of the one God, i.e., the argument from androgyny. Rabi'a, no less, is held up by the Sufi tradition as the representative (and if we push the point, an embodiment of divine) love (ishq); she too is, as we have seen, masculinised, and so the quality of mystical love is appropriated by men as something achievable by (and perhaps even, once again, on Platonic terms, for and between) men.

At the western tip of the Islamicate world, Ibn Arabi recounts four relatively obscure Sufi women that he knew that support the aforementioned point. The first is Shams, "mother of the poor" (Austin [1971] 2008, p. 142), whom he first met in her eighties and visited often. She lived in Marchena. She is described as a remarkable abstinent endowed with flawless piety. Ibn Arabi is witness to her extraordinary gifts of telepathy, prophecy, and miracles. The second is Nunah Fatimah bint ibn al-Muthanna (or Fatimah of [Cordova] Seville) (Austin [1971] 2008, pp. 143-46) with whom he had a close connection on account of her singling him out as the example student. Ibn Arabi met her when she was ninety-six (Austin [1971] 2008, p. 145). Ibn Arabi speaks of her as a pious renunciate (who "only ate the scraps left by people at their doors") and most obedient servant of God (refusing even the "Kingdom" when offered to her for the sake of God) (Austin [1971] 2008, p. 143). She is described affectionately by him as "a mercy to the world" (Austin [1971] 2008, p. 144). Her spiritual influence was so strong that God would acquiesce her wrath and her mercy toward another. For example, when a muezzin struck her with his whip, a mere look by her and the next day he was destined to be executed by the Sultan but was spared on her intercession. Ibn Arabi was witness to numerous miracles performed by her as evidence of her extraordinary spiritual ability; in particular, he notes her powers of incantation through al-fatiha ("The Opening") (Austin [1971] 2008, p. 143). The third is the "slave girl of Qasim al-Dawlah", who remains unnamed. She is described as having the gift of what might be perceived as teleportation ("the power to cover great distances quickly") and communing with nature (Austin [1971] 2008, p. 154). Ibn Arabi describes her in terms of the masculine honours of having possessed the "virtues of chivalry" and being "most strenuous in self-discipline", fasting regularly day and night. He held her to have been "strong" and that "her exertions" suited her well. He claimed that to his knowledge she had no equal in chivalry. Finally, there is Zainab al-Qal'iyyah (of the "fortress of Banu Jamad") with whom Ibn Arabi had contact "both in Seville and at Mecca" (Austin [1971] 2008, pp. 154-55). She was the "foremost ascetic" of the time, we are told, and although she possessed both beauty and wealth, "she freely abandoned the world and went to live in the region of Mecca". Having travelled with her from Mecca to Jerusalem, Ibn Arabi describes her as having no equal in religious observance and as keenly intelligent. She is described as possessing the gift of levitation. He also notes she was the companion of distinguished men of religion (Austin [1971] 2008, p. 155). The latter, according to the paradox thesis presented here, is of particular note, since it denotes that she is given the particular honour of being permitted amongst men as a 'man'—-because of her asceticism-and not as a woman. Her giving up the world is indicative of her having given up being a woman, as we shall see. Of course, the offering of these accounts from Ibn Arabi's Ruh al-Quds is not to infer his opinion as such but again to denote his documenting of the mood of the time. That is, his references all indicate that when women were praised by men, it was through their masculinisation. Indeed, asceticism and piety were male-dominant institutions, and successful participation in them would require the masculinisation of the female. At the eastern tip of the Islamicate world, there are accounts given of an obscure Sufi woman by the name of Fatimah of Nishapur. ${ }^{8}$ In the biographical traditions, she is considered one 
with great knowledge of mysteries ('arifa). She lived in Khurasan, frequented Mecca, and from there, visited Jerusalem. She is said to have been the teacher of two especially notable male Sufi figures: Bayazid Bistami and Dhu'1 Nun al-Misri. Bayazid said "[i]n my life I only encountered one real man and one real woman-Fatima of Nishapur", and Dhu'1 Nun said "[s] he is of the saints of God, and my teacher". 9

From the above accounts of lesser-known female figures, we see Fatimah of Seville and Fatimah of Nishapur, as clearly signalled in their roles as hidden spiritual guides-this, for us, is an indication of the unseen female mystic. They were surely in plain sight, yet they concealed their spiritual power, revealing it only in secret to whom they intended. To be direct, the men mentioned (Ibn Arabi, Bayazid, Dhu'1 Nun) are no less considered pillars of the mystical tradition, yet they learned their religion-their mysticism-from both men and women. This also indicates that Sufi women were held in high regard by men who recognised them. The point remains, however, that the respect for women in historical Sufism was subtle, or at least, it was subtly communicated. For instance, in the seventy-third chapter of the Futuhat al-Makkiyya, Ibn Arabi reports that when a master of the Way was asked to reveal the number of living saints in the world, he answered "[t]here are only forty"; asked why he did not say "forty men", he replied "[b]ecause there are women among them" (quoted in Nurbakhsh 2004, p. 10). The point, being elusive, is easily missed; we see the essential feminine in mysticism shine forth, but only if we can see what our authors have said about them as untainted by the conventional point of view.

This becomes particularly evident in the case of the association of 'woman' to 'world' in classical Sufism. There is a famous story related by Attar that Fatima would speak unreservedly with Bayazid about mystical matters and that when they sat in conversation, she would freely remove her veil (1905, p. 288ff). She would continue this habit until one day he noticed the henna on her hands. After that "free spiritual conversation was no longer possible between the two mystics, for 'the world' had interfered" (Schimmel 1975 , p. 427). The deliberate mention of the "world" is a euphemism for woman, and so it is synonymous with womanhood in the mind of our classical authors and storytellers. However, there is more to the story. Fatima is the teacher of Bayazid in the setting. She is said to have sat down and spoken with him without a veil (that is, one can assume, both literally and figuratively). She is speaking with a man, a non-relative, without restriction, and this is not a problem for the biographer, but what is a problem-and here comes the paradox - is that he notices the henna. In other words, she has to stop talking to him because he notices her. To be clear, the story still advances the view-albeit, most discretely and, one might say, tastefully - that her womanhood is a problem and that her being a woman is a problem. To go further, that is, in a free-interpretation of this story beyond perhaps the intentions of the narrator, even though he (as a man) notices her (as a woman)—not as freely conversant souls, as perhaps he should-the biographer does not place the fault with Bayazid but with Fatimah. The twist in the paradox is that whilst he noticed her, because of his manhood, it is she that is at fault because of her womanhood. The insinuation - in its blunt form - is that the 'world', that is, 'the woman', has interfered and thus ruined an otherwise spiritually serene situation, whereas the message, as we read it independently, is that Bayazid is taught a lesson about paying attention to the unseen aspect of the woman as the female mystic and through her into the divine feminine.

Unsurprisingly, the nafs (i.e., the lower soul, a lesser form of existence, an animallike quality, see Schimmel 1975, p. 428) is categorised as feminine. In the traditional understanding, femininity has been made synonymous with weakness of the flesh needing to be conditioned so as to aspire to spiritual life. One may wish to present Sufi aspirations to the contrary as presenting an equilibrium of male and female complementarity, as Murata would have it, but the reality is that the symbolisation of 'man' and 'woman' took on new meanings in masculinised mystical language: the 'man' of the way must surpass the level of the 'woman'.

Let us consider the 'horrid wife' scenario. Since monasticism was frowned upon by the Prophetic tradition, marriage was seen as a way of preparing for paradise by suffering 
hell on earth, and the wife played that role (of providing for the conditions of hell on earth). Jami reported that some were so opposed to, and disinterested in, women that they would not even touch food prepared by a woman (Schimmel 1975, p. 428; Jami 1957, p. 576). The well-known and humorous story recorded by Rumi in the Mathnawi of the wretch Kharaqani and his wife (Nicholson 1934, pp. 372-78) makes the point. Rumi's story portrays the classical Sufi ideal with regard to marriage: that enduring a dreadful wife enriched a Sufi man spiritually, so much that he became the master of beasts. All of a sudden, the lofty height of ascetic living was trumped by 'marital asceticism'. The irony is that the Muslim man becomes the "civic monk" (Milani 2018, p. 59). Common tropes visible in Sufi literature of the time depicted the "world' as a "decrepit old woman", her figure bent "like a bow and every sense in her decayed", yet her "lust and desire" were in full effect, "snaring" a husband (Nicholson 1934, pp. 326-27, 329-30). Conjuring such imagery no doubt references the technique of Sufi teachers wanting to convey to their disciples the dangers of worldliness "that leads nowhere" (Nicholson 1934, p. 326), and it was clearly linked to, and ground in, the desire of a man for the opposite sex. The female appeared beautiful and was desirable, but she represented, spiritually speaking, the exact opposite-so that when you have something that is the opposite of another thing it is everything that that thing was not (see also, Kugle 2007; Geoffroy 2016). In other words, Sufi men were trying to compensate for the opposite in order to counter the fleshly desire that a beautiful woman would incite in a man.

The turn in Sufi literature is late, and it is seen in the reference to Potiphar's wife (also known as Zulaikha) (Q 12). Echoing the Quranic narrative, Joseph becomes a Sufi trope for the physical representative of divine beauty on earth. Zulaikha, Potiphar's wife, is uncontrollably drawn to him. The subtleties of Sufi poetics allow for more complex ways of imagining the relationship between human and divine. Thus, Zulaikha is seen as the ideal Sufi desiring proximity with the sacred as told (in the most famous version of the story) by Jami in his Haft Awrang (Seven Thrones). Note, the reversal, now, of standards: before, a woman wanting to become Sufi had to become a man; now it seems a Sufi who wants to be a true lover has to be like Zulaikha, a woman - that is, to be like her in love with Joseph's Face. The virtue (of love) is feminine, and femininity is the virtue here. The literary shift in Sufism is comparable to the literary shift in the Christian world where we can see in Dante Alighieri's The Divine Comedy a similar idea about replacing physical desire with spiritual desire in order to attain the ultimate goal of dissolution in God. The energy of Dante's love for and physical attraction to Beatrice must be redirected to God and thus transformed into something holy. Indeed, a line from Rumi's Mathnawi, book 1, line 111 (Rumi 1939, p. 10), reads:

$$
\text { عاثقى گَر زين سر و كَر زان سر است }
$$

(Love, whether earthly or spiritual, will lead us ultimately to that king [God].)

A final example is that of Mary the mother of Jesus in the Qur'an. Rumi has a section on this in the Mathnawi, which expands on the Annunciation (Nicholson 1930, pp. 207-12), known to Western readership from Luke 1: 26-38. In reading the story, there is no mistaking the fact that woman (and not man) is absolutely central, beloved, and a source of mystical love and union in Sufism. To fully appreciate this, we need only to recall that Jesus is to Sufis the embodiment of pure Spirit, indeed, some have even said, a Sufi par excellence (Milani 2018, pp. 95-112), and so this example of a perfect being, a spotless soul, and so on-all references that are commonly found in Sufi literature about him. For all of that, this man, the enigmatic ideal, is born through a woman. He is birthed into the world through a woman and so therein lies a most subtle paradox. From the Christian point of view-and we borrow the sentiment of Umberto Eco's character, William of Baskerville-“'the Lord, who is all-powerful, could have transformed himself into a man in some miraculous way, but he chose instead to become flesh in the womb of a woman, a sign that it was not so foul after all" (Eco 2004, pp. 270-71). From the Muslim point of view, it cannot be any less 
than "we made the son of Mary and his mother a sign to mankind, and gave them a shelter on a peaceful hill-side watered by a fresh spring" (Q 23:50).

\section{Part II: The Divine Feminine}

What is the 'divine feminine'? To answer this question, we ask why Ibn Arabi considered 'Adam' in terms of insan? It was likely so as to emphasise the androgynous nature of the human and to convey a deeper understanding about using metaphysically nuanced language. The conventional reading of the Creation of Man in Christianity and Islam reads that God, without gender but holding potentiality for both, creates Adam and Eve (the male and female archetype), from whose intercourse then emerges humanity. Ibn Arabi's interpretation, however, allows for a possible alternate reading. God, essentially feminine, produces Adam (the male form) and from him Eve (the female substance) (Abrahamov 2015, p. 177). We are full circle: the female substance is the unseen divine feminine in woman and man.

Let us take a look at Rumi. He is of a more conservative persuasion than Ibn Arabi and takes a traditional outlook toward women, generally, but he does on occasion surprise his reader in what he writes. Now, in the Mathnawi Rumi says: "She (woman) is a ray of God, she is not that (earthly) beloved: she is creative, you might say she is not created" (Nicholson 1926, p. 133). ${ }^{10}$ Nicholson's rendering of Khaliq, which is conventionally "Creator", represents his poetic adaptation of the term as a verb, rather than the noun, so as to indicate the activity of the holy. This is important because it signals just how subtle such a line is as it is found in the Mathnawi. There might be many ways to interpret this incredibly abstract verse, but one possible interpretation that is opened up by Izutsu (1984) is that based on an unusual reading of the verse: "[ . . ] I have fashioned him [Adam] and breathed of My spirit into him [ . . . ]" (Q 15:29). Izutsu-drawing on classical sources and philology-asserted that the creative force underlying existence is feminine (Izutsu 1984, p. 203). Quoting the Persian Sufi scholar, al-Qashani (d. 1335), he says "the 'wife' (of Adam) was feminine. Moreover, the first unique 'soul' from which she was created was feminine" (Izutsu 1984, p. 203). Since the creation of Eve (Hawwa) is not overtly mentioned in the Quran-the passage 4:1 is key-and since the traditional knowledge about Eve's creation from the rib of Adam is derived from hadith (Sahih Bukhari: 3331), the question that Rumi poses is thought-provoking. If we free the subject of Rumi's verse from the linguistic form in which key words are placed, it might read something like the following: "She is a ray of God ... creative ... not created". The point of reference becomes irrefutable: The creative force that is the ground of being is feminine-hence, the divine feminine. This view is, of course, akin to-though not the same as-what Ibn Arabi asserted as the derivation of creation from the creative feminine, whereby, and explicitly, the feminine is the source of all beings. In Ibn Arabi's reading of tradition, the feminine gender was clearly given precedence over the masculine (Abrahamov 2015, p. 177). Therefore, in our saying that the feminine (as the creative force) is the ground of being, we do not intend to pass this off as echoing any medieval Sufi commentator, but rather it is the assertion made here in the light of the analysis provided.

There is a hadith that states: 'ina al-rahm s[h]ujna min al-rahman (Sahih Bukhari: 5988). ${ }^{11}$ It is literally (and traditionally) translated as "the womb is a branch of God", the word "branch" being key to denote an "extension" from the main part of something, in this case God. In the traditional sense, the hadith designates the importance of family and close relations. In this sense, therefore, it shares the value of being good to one's family or with those with whom one relates. It could be said that the hadith underlines the idea of ihsan (virtue) with regard to human relations. That is, it sets the highest standard of conduct for humans in relation to each other, this being underpinned by mercy, compassion, and kindness. In another sense, which is not too distant from the typical reading of the hadith given above, it can also be said that the hadith might be suggesting that perhaps the womb, which is "a locus of God's life-giving mercy" (Murata 1992, p. 182), is quite simply analogous to the act of divine creation, which is imbued with ceaseless mercy. In 
this reading, al-rahm is clearly derived from al-rahmah, even though there might only be a vague linguistic connection, if at all. In both instances, what is clear is the allusion to what connects or links the divine and human. The answer: compassion. Were we to replace "branch" with "roots" (from the alternate reading of shujna, meaning "closely connected"), then this meaning would be doubly emphasised, if not piercing. ${ }^{12}$ At this point, and in the context as hitherto laid out, the assertion might be made that the womb can be interpreted as figuratively as mercy/compassion. To make the point more strongly, the symbolic association of al-rahm to al-rahman has in the past been made-that is, "womb" to "God"since both closely exhibit elements of mercy, compassion, and love. ${ }^{13}$ If so, and in a highly unorthodox fashion, the hadith can be rendered to mean: "mercy comes from the merciful" (leaving the translation of al-rahman ambiguous so as to indicate both someone who is merciful, whilst also denoting God, the all-merciful), and in a most provocative and freely translated sense, playing on the word sujna to not only mean "derived" but in particular to mean "held/contained within", the hadith may have meant to read: "God is hidden in the womb". This latter encompasses the sum of the translations and meanings discussed.

Whilst the latter statement is contentious, the basis of its proposition relies upon an etymological argument connecting the term "womb" to al-rahman and thus linked to what is generally held to be the most powerful verse in the Quran: al-fatihah, within which (and subsequently in all but one chapter) we read the bismillah. Furthermore, the womb, being a place of origin, is the ground wherein a seed might be kept for a time for it to come to fruition. Thus, the analogy is of the seed planted under the surface where it is kept safe until it grows and breaks through the surface of the earth and comes up and appears as that which it is. The word al-rahman in any case simultaneously contains both meanings- "mercy" and "womb" - in the Arabic. Either way, it leads back to the idea and significance of the divine feminine; since al-rahman denotes kindness, mercy, and compassion, it is undoubtedly connected to love. If we allow ourselves to make more of the following verse in the Mathnawi than is perhaps reasonable (given Rumi's mostly traditionalist outlook), it might suffice to say, at the very least, on some conscious level, Rumi is aware of his deliberate allegorisation of God as "Mother" (Nicholson 1934, p. 44; see also Taheri 2011, p. 142 on the view of Rumi's son and founder of the Mevlevi Order, Baha Valad). Something might be said for invoking "Moses" in that same passage that speaks to the obvious trope of the divine as feminine in mystical thought. Moses, we will recall, was committed to water by his birth mother and pulled from water by his foster mother (Pharaoh's wife); he then emerged as prophet to face Pharaoh. That woman behind the active narrative of salvation (both of Moses and of the Hebrew slaves under Pharaoh) is worth further consideration. Pharaoh is a figure powerless in the face of 'God's plan' (that is to say, His keeping Moses alive), and Pharaoh is unable to destroy either Moses or the Hebrew; rather, Pharaoh ultimately destroys himself when the waters fall in on the Egyptians in pursuit. Rumi's conjuring of "Mother" and "nurse", including "Moses", who brings to mind the waters, presents an interesting afterthought in what could be rendered an alternative reading of the divine feminine. However, Rumi's traditional sensibilities, far from interfering with a reading of the divine feminine, in actual fact reinforce it. Not only is he aware of God as "Mother", but he, along with Ibn Arabi, is also mindful of God's primordial virginal activity (with particular reference to Mary mother of Jesus), as will become clear. His traditionalism betrays the much older entrenched Arab-Bedouin custom of the wet-nurse, which is intimately connected to the biography of the Prophet. The hadith about the woman who nursed (i.e., offered of her breast milk to) children not her own because they were without their mother is of note. Here, the Prophet asks his Companions: "Do you think that this woman can throw her son in the fire?" They replied, "No, if it is in her power". The Prophet said: "God is more merciful to His slaves than this lady to her son" (Sahih Bukhari: 5999). If we are to accept this narration, then there is something to be said about the pre-eminence of the female substance as woman being representative of the divine feminine as essence. Even if this hadith might be asserted as being used derogatorily (as in, put into the mouth of the Prophet) by tradition, as if to say 
that 'if a woman can do it, so can you', it nevertheless does not fail to convey the point that God's mercy is being linked to a feminine quality.

The sense of 'softness' to these references might draw the kind of criticism that Islam has its 'soft' as well as 'hard' side, and this would be unquestionably something of a chauvinistic commentary, that is, to see the female as 'soft' (as if to suggest weakness). The hadith narrative certainly suggests strength of a different kind, the idea being to pose the question that is not typically considered by the men in Muhammad's company (that is, to those with whom he shares the parable of the nursing woman). Indeed, we could go further to assert that even in the male-centric view of seeing the female as soft and weak, the deliberate use of the hadith about the nursing woman was meant to demonstrate to readers that the perceived 'softness' and 'weakness', i.e., vulnerability, of woman is in fact no trivial thing-it is the mark of great strength, and, perhaps even ironically, the mark of a 'real man'. One might even dare say it is the most perfect mystical state. Might the hadith, then, which comes from (or is put into) the mouth of the Prophet, be an invitation to men to enter into this 'female experience' of the divine? It would appear so, since we can easily take it as support for the reversal of the so-called ideal in early Sufism that a woman must become a man to be a Sufi. As the mystical and the feminine have in common the elements of love, mercy, and compassion, the underlying irony in the Sufi message, it would seem, is, at the very least, tongue-in-cheek — that men must become like women! It should then be clear by this point that the conventional reading of traditional Sufi mystical ascension-as comprising the transcendence of worldly binaries in order to attain to union with God-remains an unsuspecting one, because, in effect, it is a position inattentive to the irony at play in Sufi language. From an observation of the works of Rumi and Ibn Arabi, what becomes increasingly evident is that the divine feminine is God's unseen quality-not as in secret, but as having been concealed from perceptibility because of the reinforced masculine reading of tradition. We do not deny that man and woman could contain within them masculine and feminine qualities, but this reflects the paradox of their material existence. However, God is non-material and Absolute-existent (واجب الوجود). Therefore, we cannot speak about God in the same way as we can about existents. As such, it is reasonable to think that a 'man' becoming a 'woman' - as the inverse to the traditional Sufi view of a 'woman' becoming a 'man' - is both necessary and essential for mystical transformation if the divine feminine is the ground of being. That is, rather than say neither are relevant because of the predominant metaphysical premise that union with the divine is to transcend binaries, we suggest that the view about the divine feminine argued here upturns the interpretation of transcendence as a unitive experience in favour of a singular and definitive source. There would be no point in dismissing or turning a blind eye to the reality of gender binaries in Sufi thought. That woman and man are differentiated by certain 'given' qualities is a given in the literature. However, that these qualities are interchangeable and, in some cases, inversed is unmistakable.

Let us return to the figure of Mary, mother of Jesus, again, as our closing example. The account of Mary is quite consistent across the New Testament and the Quran. Regardless of a Christian or Muslim reading of these texts, the central theme of the divine feminine is pronounced in both. We read that Mary was pregnant with the sacred and gives birth to a holy being. She is a vessel of God. Now, we know that the prophets of God (overwhelmingly men) are thought of as 'vessels' metaphorically by tradition-i.e., as those without self, chosen to carry the message of God. Yet with Mary, this point is of particular interest, especially in the context of Islam, since the virgin birth of Jesus is to be "a Sign to mankind" and "a blessing" from God (19:21). One could take the sign further to mean a direct interjection from God to man in defence of woman in the passage where the baby Jesus speaks from the cradle to rebuke Mary's attackers (19:28). Moreover, in the Gospel of Matthew, wherein the genealogy of Jesus is given, the chain of names of men is interrupted by the singular mention of a woman who "begot" Jesus, the Christian saviour (Mt. 1:16). Indeed, the traditional story about Mary being dedicated to the temple in preparation for her role as Theotokos is preserved in the Quran (albeit in a minimalist sense and stripped 
of Christological assertions), where it is said that Mary sought solitude for a time in a place far away in the East (i.e., Jerusalem) (19:16). Undoubtedly, then, Mary is an exemplar of chastity, purity, and fullness in the divine - that is, pregnant with the divine, symbolically speaking, because of her dedication to God-in anticipation of her spiritual reward of being what Orthodox tradition refers to as "God-bearing". Furthermore, her story also resembles the seclusion of a place hidden from society, a womblike place, where she is visited by the Spirit of God (19:17-19). To explain, woman is the revelation of the secret god is famously attributed to Ibn Arabi and the manifold ways in which one can explore the divine feminine also peculiar to him. Thus, it is no surprise that he, unlike those interested in "gazing at beardless youth", was well-disposed to women instead, knowing full well the secret they embodied. He says in the Futuhat al-Makkiyya:

Whoever knows the worth of women and the secret contained within them will not refrain from loving them. Indeed, love for them is part of the perfection of the knower of God. For such love is a legacy from the Prophet and a divine love. And the Prophet says: "They were made dear to me (perfume and women)". Thus he designates no one other than God Himself as the cause of love for them (Ritter [1955] 2013, p. 494; 1911: 2/190).

That Jesus was given the title Seal of Saints not only signals his own perfectionhaving been conceived of the mixture of "imagined and real water"-but also his mother's. The conjugation of Gabriel and Mary, as implied by Ibn Arabi's reading of the Quran, occurred "in the usual way" (i.e., in the manner of "this human species"), he tells us, but it happened in such a way that preserved the secrets of creation therein, since it was only after putting her mind at ease (that he was there from God to give to her a "pure son") that "he blew Jesus into her" (Abrahamov 2015, p. 105).

Let us bring some of the key thoughts of this section into view. Though a difficult point to make in the light of normative readings of Islamic religious experience, we have wanted to show the real strength of the correlation between mysticism and femininity in the Islamic lifeworld (as is widely understood in studies concerning other religious experiences—see, for example, Cusack and Prior 2015; Schmidt 2016; Knight 2011). We have done this by drawing on examples from Islamic sources that disclose such affinity between mysticism and femininity but which are normally drowned out by the dominant conservative narrative. Notwithstanding, what we have argued is that the mystic is feminised in being taken over by the sacred as feminine. Thus, regardless of sex or gender, the mystic is made to reflect the divine feminine source that it now mirrors. Indeed, to finish with the provocative example of Jesus in the Qur'an, our intention is precisely to portray just that-the power of the divine feminine as the source of the experience of the sacred in mysticism.

\section{Part III: Two Sufi Women of the Medieval World}

This final section provides a brief comparative analysis of two Sufi women: Julian of Norwich (d. 1416) and A'ishah al-Ba'uniyyah (d. 1517). This section offers broad reflections on what has hitherto been discussed, now in relation to the aforementioned figures. Julian and A'ishah are treated as portraying comparable examples of mystical experience from two markedly distinct religions. In our undertaking, we have mainly consulted Barry Windeatt's critical translation of Julian's revelations (2015), not least because we found it accessible and believe it will be helpful to readers should they wish to pursue reading her visions in whole. (There, literature on Julian of Norwich is extensive. We offer here a short list of those studies that have been of specific interest to our particular analysis of the figure: for a study of her theology, see (Jantzen 1987; Sheldrake 2019); on her deinstitutionalised value, see (Cusack 2020). Concerning Neoplatonic correlations, see (Baker 1994, esp. 118-120) and also (Cuda 2009, esp. 59)). For A'ishah, we rely solely on Th. Emil Homerin's translation (2014), which is presently the only critical edition available to the English-speaking world. Until now, we have looked at the women of the Sufi world through the prism of men. Even where we have observed the accounts of renowned 
Sufi women (Rabi'a, Fatimah of Seville, Fatimah of Nishapur), access to them was almost always framed by the account of men (Attar, Ibn Arabi). What follows, therefore, is an examination of two accounts of mysticism from the first-hand experience of one Christian and another Muslim woman of the medieval period, roughly a century apart. In the writing of both, what is readily noticeable is the trace of the (Neo-)Platonic schema. For we read Julian confess "our substance is in God, and I also saw that God is in our sensory being" (Windeatt 2015, p. 121), and A'ishah composed "He turned to them and revealed to them His essence. And they lived again gazing at that living face as His eternal life appeared" (Homerin 2014a, p. 159). This is notable for the reason that the framework of both of them is dependent upon a Neoplatonic extension from and return to the One. This is conceived by Julian as beloved offspring having come forth from God that "by nature shall be brought back within him by grace" (Windeatt 2015, p. 136) and by A'ishah as the sublimation and "absorption" of the lover whose "shadowy existence passes away with promised grace" (Homerin 2014a, p. 143). Yet, in both, what is also present is the Dionysiac mood-as in the underlying current of enigmatic and uninhibited emotional content bearing the marks of the initiatic mystery-cult-in terms of how the relationship to God is experienced.

Julian of Norwich is the celebrated medieval English anchoress and author of a book known as "Revelations of Divine Love". The work is of a subtle nature that offers profound thinking behind it, which emerged from the revelations she experienced in 1373 whilst recovering from serious illness. In the book, she describes her visions during the time of her suffering, where she is shown a loving and compassionate God, merciful and forgiving despite the human proclivity for sin. Julian is regarded as having provided a strikingly independent theological view, one notable feature of which was her account of God as our mother.

Having been shown something of the mysteries of the divine, in her direct revelation of her Lord Jesus, her visions provide direct access to an experiential understanding of God as mother. What is unique about this experience of hers is that she feminises the experience of Jesus by way of simile. Now, she is not the first to draw on maternal imagery in discussing God the Creator, but she is distinctive in her feminisation of the experience of Jesus. Whilst references in the Old and New Testament offer sustainable grounds for doing so (such as Isaiah 42:14 and Mt. 23:37), these are not more than instances where metaphor is employed to convey meaning (that is, the example drawn is incidental and not detrimental to the point). Indeed, in Julian's writing, she is putting into force her meaning of Jesus "the heavenly mother". Still, her revelation on this is grounded in tradition-the Church is the mother of the faithful, and since she is the body of Christ, Jesus is "our mother" in this life and we are children to her. She says the "gracious hands of our mother are ready and enfold us diligently; for in all this he performs the role of a kindly nurse who has nothing else to do but attend to the safety of her child" (Windeatt 2015, p. 133). Incredibly poignant is the language employed by Julian in describing our connection to God through her reading of the incarnation. She takes this to be as symbolic of the womb in which we are kept until our maturity in the next life: "our Saviour is our true mother in whom we are endlessly born, and out of whom we shall never come to birth ... we are all enclosed in him and he is enclosed in us" (Windeatt 2015, p. 126). We must also keep in mind that Julian's reference to 'mother' within the Christian context carries the double sense of both 'mother' and 'virgin', and as such, hers is a view aware of the 'virginal state' when speaking about God as mother. Indeed, 'mother' in the Christian context is by virtue of Mary (the mother of Jesus), who is a virgin.

A'ishah al-Ba'uniyyah of Damascus was a distinguished female scholar who was a mystic and a prolific poet and writer. In a surviving work, Kitab al-Muntakhab fi Usul al-Ratab fi' Ilm al-Tasawwuf, translated in short by the late Th. Emil Homerin (d. 2020) as The Principles of Sufism, she demonstrates love as God's greatest secret. Unlike Julian, $A^{\prime}$ ishah was not the exception in being an educated woman in her time and society. Not only was she free to produce numerous works of importance that were read and cited, but as a mystic, she was both recognised by her male contemporaries and authoritative. 
In comparison to Julian's book, situated in her Christian world, A'ishah's book, in her Muslim world, is distinct not because it was written by a woman, but precisely because its language, tone, and style are not gendered. Whilst it was assumed by its translator as possibly the first Sufi guidebook written by a woman, it would be, as he admits, impossible to determine the gender of the author based solely on its content (Homerin 2014b).

Nevertheless, it would not be out of place to suggest that since love is not only central but also the key to A'ishah's Sufism, it betrays not gender but the inherent femininity of the hidden religion of love (madhab-e 'ishq) within Islam. It is, therefore, no accident that A'ishah opens the chapter on the fourth and final principle (at the apex of the book) on love with the following quote (from Quran 3:31): "Say, 'If you love God, then follow me, and God will love you!'" (Homerin 2014a, p. 97). Her commentary on the verse reveals her belief that love is both a hidden layer of religion and the most secret aspect of faith. In striking similarity to Julian, A'ishah, referring to the remainder of verse 3:31 ("God loves you and forgives your sins") says:

The "and" here, denotes a sequence so that it is clear that love is prior to forgiveness: first, He loves them; then they love Him, and then He forgives them, as they ask His pardon. Love thus necessitates forgiveness, because to forgive necessitates love (Homerin 2014a, p. 97).

For A'ishah, "love" indicates the "purity of states" (Homerin 2014a, p. 97), and in the closing section of her book titled "Epilogue on Love", she affirms love's secret:

The subtle meaning of God's love for the worshipper is the selection of the worshipper for this secret-which we have noted and to which we have referredby seizing him with the Beloved's attractions and effacing annihilations until the worshipper is without a sense of self in the light of the sun of true oneness. This is the true realisation of true love. Anything less than this love is a love dependent on causes and contingencies derived from attention to the pursuit of pleasure and the avoidance of pain (Homerin 2014a, p. 157)

To close, our case studies offer palpable evidence for arguing a probable deeply personal and experiential comprehension of the divine feminine. Not least, the historical example of their persons provides irrefutable substantiation of the distinguished role and presence of the female mystic in both Christianity and Islam. Moreover, detectible in both is the (Neo-)Platonic and Dionysiac tension, which defines a more profound, more historic mysticism. In fact, both Julian and A'isha provide us with an opportunity to reflect on something more: in their deeply felt mysticism, they reveal what is in fact beyond the merely religious, that is, they show their reader a way into the mysteries beyond the surface of what is the religious world of men.

\section{Conclusions}

The divine feminine and the female mystic are on the one level representative of a consistent and coherent symbolism of the source of creation as manifest in mystical currents within Islamic history. Yet, on another level, we have argued that these are more than symbolic: they are demonstrative of the deep-rooted experiential apprehension of the mystical understanding of God. As such, the divine feminine and the female mystic are, therefore, fundamentally not about the depiction of 'woman' (as in sex/gender representation) as we find it, but rather what it is to be in connection to the divine that can become apparent through its unconcealment. The attempt of Sufi theoreticians in the past has been to make use of the idea of God as being beyond gender so as to neutralise the masculine bias in tradition, and whilst they have provided a more sophisticated interpretation (of what still remains a misogynistic reading of tradition), we have found it wanting given the anomalies found with regard to mystical experience. Rumi's poetry and Ibn Arabi's metaphysics (as well as the hermeneutical tradition he inspired) have certainly provided support for the view that 'God', as the ground of the sacred, is, in essence, a creative force, and thus feminine. However, there is also the suggestion there, we would 
like to think, that what is mystical is by nature female and mystical experience feminine. Therefore, it would appear that both Rumi and Ibn Arabi may have been inclined toward the view that the mystic - whether a man or woman-takes on the 'female' quality in entering into mysticism and is thus by nature engaged in a phenomenon that is essentially feminine. The 'female mystic', in this sense, denotes a state of being that is beyond the seemingly Sufi woman or man as gender; it is as such the quality of the mystical that is in touch with the feminine creative force (God). We might further say that it is not that Sufi women and men must transcend their gender to achieve unification with God, but rather that they each must enter truly into the 'female' quality of the feminine source of existence in order to do so. The phenomenon of the female mystic is more than the identification with gender-specificity. Indeed, it is the clearest-and in contrast to traditional means of verifying the sacred, the closest—-mode of appearing of the divine feminine, the sacred ground of all existence.

All the while, we have made clear three kinds of ways in which the feminine is latent in the originary function of Sufism. In our search for understanding the phenomenon of the 'female[-]mystic', we have had to distance ourselves from the social and cultural, and thus gendered, interests in the woman Sufi. This is because the phenomenon of the female mystic, in our asking about it, is not representative of gender but rather fundamental to our seeking to know what it is as the condition of existence that presents to us the mystical in Sufism. We might ordinarily refer to the Sufi woman also as a female mystic, but this would be to merely shuffle words. What we mean by the 'female mystic' is the way of being present to the divine where God's feminine essence is manifest through the female quality of the mystic. For the woman Sufi, this way of being would set them apart from other ways that women are religiously made to appear in history. What we have meant by the 'divine feminine' is that which has always been the underlying aspect of this unfolding in history. As such, the question of gender does not pertain to a Sufi as either a man or a woman because the phenomenon itself is gendered in a much more fundamental and originary way. It should be clear, therefore, that this study has not been about the grafting of a gendered argument onto a metaphysical reading of Islam (in terms of the masculine and feminine aspects of the divine-as has already been performed by Ibn Arabi and his interpreters) nor has it been about the representation of the divine likewise (manifest or inherent) in the corporeality of male and female. Our focus has been about metaphysics so far as it is a study of ancient metaphysics, that is, what is beyond the visible formality of the woman, female, and feminine.

Implicit to our analysis has been the view about a further distinction to be made about religion and mysticism, again, not as categories, but as what they reveal upon closer investigation as distinguishable phenomena. In doing so, we want to avoid the hard distinction made between religion and mysticism; indeed, Sufism is a clear example of just how fluid this boundary can be. So, to finish, we ask whether 'religion', that is, Islam, as revealed tradition overwhelmingly shaped by men, is 'male' by quality and masculine in essence? If so, then 'mysticism', that is, Sufism, as concealed tradition, must be in turn 'female' by quality and feminine in essence. We say this so as not to delimit Islam and Sufism in absolute terms, but to show how the ratification of its activity can be signified as such, even though, in view of our inquiry, the exchange between the two has always been and will remain open. The distinction we wish to make is that each reveals in the ordinary a part of what remains concealed.

As such, Islam as religion is masculine in so far as it is phenomenologically underpinned by related primal instincts that are outwardly directed: desire, conflict, and domination. Sufism as mysticism is feminine in so far as it is phenomenologically underpinned by those basic instincts that are inwardly facing and reflect receptivity, gentleness, and empathy. Yet, to conclude, we might dare say the concealed aspect of religion and mysticism remains the primordially conceived divine feminine and its corresponding representative the female mystic. 
Author Contributions: Conceptualization, M.M.; methodology, M.M.; formal analysis, M.M. and Z.T.; investigation, M.M. and Z.T.; resources, Z.T.; writing—original draft preparation, M.M.; writingreview and editing, Z.T. All authors have read and agreed to the published version of the manuscript.

Funding: This research received no external funding.

Acknowledgments: The authors wish to thank their colleague and co-editor of the Special Issue, Aydogan Kars, for his valuable feedback on earlier drafts of this article. We are indebted to Ali Zwayen and Ali Hammoud for their help with Arabic. The authors are particularly grateful to the anonymous reviewers for their suggestions for improvement. The authors also wish to offer a special thanks to the assistant editors and production team in preparing this article for publication.

Conflicts of Interest: The authors declare no conflict of interest.

\section{Notes}

1 For background on the early history of Sufism, see Karamustafa (2007).

2 For this, see the work of Scott A. Kugle.

3 Indeed, Sana'i is known in the history of Persian literature as the most hostile Sufi poet toward women. The Farsi reads: من غلام زنى كه از صد مرد بخزرد روز بار و بردا برد mel's translation is interpretive so as to convey the meaning of the idea comminated by Sana'i in the story of a devoted woman.

4 Her apogee work on the subject of women in Sufism (Schimmel 1999) brings to bear the full extent of her Sufi apologetics.

5 In addition to al-Sulami's work cited above, one might also consider the following works: Ibn Arabi's Ruh al-Quds; Ibn al-Abbar's (d.1260) biographical dictionary, Takmilat Kitab al-Sila; and Ibn Rushayd work, Mal al-'ayba fi ma jumi'a bi-tul al-ghayba fi al-rihla ila Makka wa Tayba (d.1321).

6 جون زن در راه خداي مرد بود او را زن نتوان گفت (chon zan dar raah-e khodaayi mard bovad zan natavan goft).

7 Augustine, in following Plato and appropriating Platonic philosophy to inform his Christian theology, believed (to put it crudely) the body was corrupt and instead gave primacy to the abstract ideal and spiritual essence of existence the ground of its reality-i.e., the Platonic $\psi v x \eta$ ("psyche").

8 See Jami, Nafahat al-uns; Ibn al-Jawzi, Sifat al-safwa; and Sha'rani, Tabaqat al-kubra (quoted in Nurbakhsh 2004, pp. 107-8).

9 Quoted in Nurbakhsh (2004).

10 يرتو حقست آن معشوق نست، خالقست آن خوئا مخلوق نلست (Mathnawi book 1, line 2437; see Rumi 1939, p. 111) (parto haqqasst aan ma'shooq neest, khaaleqasst aan gooya makhlooq neest).

11 This hadith can be transliterated in the following ways: 'ina ar-rahimu s[h]ijnatun min ar-rahman, 'ina ar-rahimu s[h]ajnatun min ar-rahman, 'ina ar-rahimu s[h]ujnatun min ar-rahman. This is to take into account what is generally agreed upon regarding how it is to be read correctly with either a fatha, shammah, or kasra, where the meaning remains the same.

12 On the translation of shujna, see Lane (1863: 1/1509-10).

13 See Ibn Arabi's interpretation of this hadith in futuhat al-makiyya (1911: 3/88) (futuhat III 88.28; cited in Murata 1992, p. 182). For more references on the symbolic reading of "womb", see Murata (1992, p. 215ff). On the association of the terms in Arabic, consult Mu'jam lisan al-Arab, volume twelve, page 232; Mufradat al-fadh al-Quran fi al-Raghib al-Isfahani, page 191; and Ataeb al-kelam fi bayan selat al-rahm, page 25 .

\section{References}

\section{Primary Sources}

Ali ibn Abdel Alee Al-Karaki al-Ameli. 1973. Ataeb Al-Kelam fi Bayan Selat Al-Rahm. Edited by Seyed Ahmed Hussaini. Qum: Mehr publishing house.

Al-Raghib Al-Isfahani. n.d. Mufradat al-fadh al-Quran. Edited by Muhammad Sayed Qilani. Beirut: Dar al-Marifah.

Attar. 1905-1907. Tadhkirat al-Auliya. Edited by Reynold A. Nicholson. 2 vols. Reprint. London: Luzc.

Ibn Arabi. 1911 (1329h). al-Futuhat al-Makkiyya. vols. 1-4. Cairo (n.p.).

Ibn Mandhur. 1999. Lisan al-Arab, 3rd ed. Edited by Amin Muhammad Abdul Wahab and Muhammad Sadiq al-Ubaidy. 12 vols. Beirut: Dar Ehia al-Tourath al-Arab.

Jami. 1957. Nafahat al-uns. Edited by M. Tauhidipur. Tehran (n.p.).

Rumi. 1939 (1375h). Mathnawi-i ma'nawi. Edited by Badi' al-Zaman Forouzanfar. Tehran: Enteshararat Safi-alishah.

Sana'i. 1950. Hadiqat Al-Haqiqat Wa Shari'at at-Tariqat. Edited by Mudarris Razawi. Tehran (n.p.). 


\section{Secondary Sources}

Abbas, Shaheem Burney. 2002. The Female Voice in Sufi Ritual: Devotional Practices of Pakistan and India. Austin: The University of Texas Press.

Abrahamov, Binyamin. 2015. Ibn Arabi's Fusus al-Hikam: An Annotated Translation of the "The Bezels of Wisdom". Abingdon: Routledge.

Arberry, Arthur J. 1983. Muslim Saints and Mystics: Episodes from the Tadhkirat al-awliya (Memorial of the Saints) by Farid al-Din Attar. London: Routledge. First published 1966.

Austin, R. W. J. 2008. Sufis of Andalusia: The Ruh Al-Quds and Al-Durrat Al-Fakhirah of Ibn Arabi. Abingdon: Routledge. First published 1971.

Austin, R. W. J. 1984. The Feminine Dimensions in Ibn Arabi's Thought. The Journal of Muhyiddin Ibn Arabi Society 2: 5-14.

Baker, Denise Nowakowski. 1994. Julian of Norwich's Showings: From Vision to Book. Princeton: Princeton University Press.

Bashir, Shahzad. 2011. Sufi Bodies: Religion and Society in Medieval Islam. New York: Columbia University Press.

Cornell, Rhia E. 1999. Early Sufi Women: Dhikr An-Niswa Al-Muta'abbidat As-Sufiyyat. Louisville: Fons Vitae.

Cuda, Anthony. 2009. W.B. Yeats and a Certain Mystic of the Middle Ages. In Julian of Norwich's Legacy: Medieval Mysticism and Post-Medieval Reception. Edited by Sarah Salih and Deinse N. Baker. New York: Palgrave Macmillan.

Cusack, Carole M. 2009. The Return of the Goddess: Mythology, Witchcraft and Feminist Spirituality. In Handbook of Contemporary Paganism. Edited by Murphy Pizza and James R. Lewis. Leiden: Brill, pp. 335-62.

Cusack, Carole M. 2020. Julian of Norwich: From Medieval Catholic Anchoress to Tourist Attraction. Literature E Aesthetics 30: 178-92.

Cusack, Carole M., and Jason H. Prior. 2015. Religion, Sexuality, and Spirituality. London: Routledge.

Diaz, Marta Dominguez. 2015. Women in Sufism: Female Religiosities in a Transnational Order. Abingdon: Routledge.

Eco, Umberto. 2004. The Name of the Rose. London: Vintage Books.

Elias, Jamal. 1988. Female and Feminine in Islamic Mysticism. Mustlim World 78: 209-24.

Geoffroy, Eric. 2016. The Eternal Feminine in Sufism: Readings of Ibn 'Arabī and Emir Abd el-Kader. Religions: A Scholarly Journal 2016: 56-63. [CrossRef]

Holtzman, Livnat. 2019. Anthropomorphism in Islam: The Challenge of Traditionalism (700-1350). Edinburgh: Edinburgh University Press. Homerin, Th. Emil. 2014a. The Principles of Sufism: A'ishah al-Ba'uniyyah. New York: New York University Press.

Homerin, Th. Emil. 2014b. Ambiguity, Optimism, and Grace: An Interview with Th. Emil Homerin on Translating A'ishah alBa'uniyyah. New York: Library of Arabic Literature: NYU Press. Available online: https://www.libraryofarabicliterature. org/2014/ambiguity-optimism-and-grace-an-interview-with-th-emil-homerin-on-translating-\%CA\%BFaishah-al-ba\%CA \% BFuniyyah/ (accessed on 10 February 2021).

Izutsu, Toshihiko. 1984. Sufism and Taoism: A Comparative Study of Key Philosophical Concepts. Berkeley: University of California Press. Jantzen, Grace. 1987. Julian of Norwich: Mystic and Theologian. New York: Paulist Press.

Jeanmaire, Henri. 1951. Dionysos: Histoire du Culte de Bacchus. Paris: Payot.

Karamustafa, Ahmet T. 2007. Sufism: The Formative Period. Edinburgh: Edignburgh University Press.

Kars, Aydogan. 2019. Unsaying God: Negative Theology in Medieval Islam. Oxford: Oxford University Press.

Knight, Jennie S. 2011. Feminist Mysticism and Images of God: A Practical Theology. St Louis: Chalice Press.

Kugle, Scott A. 2007. Sufis E Saints' Bodies: Mysticism, corporeality, ESacred Power in Islam. Chapel Hill: University of North Carolina Press.

Lane, Edward William. 1863. An Arabic-English Lexicon. London: Williams and Norgate, 8 vols.

Langhi, Zahra. 2009. Ajami Mysteries of Sitt 'Ajam Bint al-Nafis: A Feminine Hermeneutics of an Heiress of Ibn Arabi. The Journal of Muhyiddin Ibn Arabi Society 46. Available online: https:/ /ibnarabisociety.org/sitt-ajam-bint-al-nafis-fatima-langhi/ (accessed on 10 February 2021).

McGinty, Patrick. 1978. Interpretation and Dionysos: Method in the Study of a God. The Hague: Mouton Publishers.

Milani, Milad. 2014. Sufism in the Secret History of Persia. Abingdon: Routledge.

Milani, Milad. 2018. Sufi Political Thought. Abingdon: Routledge.

Milani, Milad, and Marley Krok. 2020. The Paradox of Gendered Holiness in Islamic Mysticism. In Islam, Civility and Political Culture. Edited by Milad Milani and Vassilios Adrahtas. Cham: Palgrave Macmillan.

Murata, Sachiko. 1992. The Tao of Islam: A Sourcebook on Gender Relationships in Islamic Thought. Albany: State University of New York Press.

Nicholson, Reynold A., ed. 1926. Mathnawi-i ma'nawi. London: Gibb Memorial Trust, vol. 2.

Nicholson, Reynold A., ed. 1930. Mathnawi-i ma'nawi. London: Gibb Memorial Trust, vol. 4.

Nicholson, Reynold A., ed. 1934. Mathnawi-i ma'nawi. London: Gibb Memorial Trust, vol. 6.

Nurbakhsh, Javad. 2004. Sufi Women. London: Khaniqahi Nimatullahi Publications.

Pemberton, Kelly. 2010. Women Mystics and Sufi Shrines in India. Columbia: The University of South Carolina Press.

Ritter, Helmut. 2013. The Ocean of the Soul: Men, the World and God in the Stories of Farid al-Din Attar. Leiden: Brill. First published 1955.

Ruether, Rosemary Radford. 2005. Goddesses and the Divine Feminine: A Western Religious History. Berkley: University of California Press.

Schimmel, Annemarie. 1975. Mystical Dimensions of Islam. Chapel Hill: The University of North Carolina Press.

Schimmel, Annemarie. 1982. Women in Mystical Islam. Women's Studies International Forum 5: 145-51. [CrossRef]

Schimmel, Annemarie. 1999. My Soul is a Woman: The Feminine in Islam. New York: Continuum. 
Schmidt, Bettina E. 2016. Spirits and Trance in Brazil. New York: Bloomsbury.

Seaford, Richard. 2006. Dionysos. Abingdon: Routledge.

Sedgwick, Mark. 2016. Western Sufism: From the Abbasids to the New Age. Oxford: Oxford University Press.

Shaikh, Sa'diyya. 2012. Sufi Narratives of Intimacy: Ibn Arabi, Gender, and Sexuality. Chapel Hill: The University of North Carolina Press.

Sheldrake, Philip. 2019. Julian of Norwich: "In God's Sight": Her Theology in Context. Chichester: Wiley Blackwell.

Smith, M. 1928. Rabi'a The Mystic and Her Fellow-Saints in Islam. Cambridge: Cambridge University Press.

Taheri, Zahra. 2011. Hozur-e Peyda va Penhan-e zan dar Mutun-e Sufiyyeh (The Absence and Presence of Women in Persian Sufi Texts), 2nd ed. Tehran: Nashr-e Sales.

Windeatt, Barry. 2015. Julian of Norwich: Revelations of Divine Love: A New Translation (Oxford World's Classics). Oxford: Oxford University Press. 